\title{
Aniversário de 10 anos
}

Quando escreveu seu primeiro editorial, em setembro de 1996, Dr. Laurindo Furquim discorreu sobre a evolução da Dental Press, empresa criada seis anos antes com o objetivo inicial de traduzir artigos estrangeiros para os ortodontistas, além de oferecer apoio àqueles que necessitassem de pesquisas bibliográficas. Naquele editorial, ainda, refletia sobre o amadurecimento conquistado com a experiência anterior: "Esta será uma publicação destinada à comunidade ortodôntica e demais interessados, com o objetivo de compartilhar conhecimentos, divulgar experiências clínicas e publicar resultados de pesquisas, dentro de uma busca constante pelo aprimoramento de uma especialidade que reúne, em si mesma, arte e ciência. Durante todos estes anos a Dental Press utilizou seus veículos de comunicação para a divulgação da ciência ortodôntica. Continuará com esta conduta editorial, porque acredita na liberdade de expressão de várias correntes existentes e no debate aberto que fomenta a investigação".

O desafio estava lançado! Todos os envolvidos naquele momento iniciaram uma corrida em busca do melhor conteúdo, edição após edição. Passados 7 anos, Prof. Furquim, avaliando o meu amadurecimento, como um dos membros do conselho editorial desde o início, nomeou-me Editor. Que responsabilidade? Aceitei aquele novo desafio, impulsionado pelo anseio de alcançar patamares ainda mais altos para a Revista Dental Press de Ortodontia e Ortopedia Facial. Em meu primeiro editorial (set./out./2003) escrevi: "Consciente da transparência de decisões que minha função exige, espero corresponder às expectativas da classe ortodôntica nacional e promover, nessa publicação, as mudanças necessárias, tendo em mente a importância de conservar o que já foi consagrado". Juntamente com uma maravilhosa equipe, de diagramadores, revisores, conselheiros etc, seguimos a política exaltada no primeiro número com todo afinco. $\mathrm{E}$, gradualmente, pudemos aumentar o rigor das revisões, agilizar o fluxo editorial, formatá-la cada vez melhor, segundo padrões internacionalmente reconhecidos, e há quase um ano o trabalho de todos nos rendeu a sonhada inclusão na coleção SciELO!

Hoje, portanto, o que foi escrito no primeiro editorial da Revista Dental Press de Ortodontia e Ortopedia Facial pelo Prof. Furquim cumpre-se ipsis litteris e mais: com acesso livre a todos os interessados e sem fronteiras.

Nesta edição comemorativa temos, como Tópico Especial, um artigo sobre a análise facial subjetiva, reforçando a aplicabilidade clínica deste padrão de diagnóstico.

Como entrevistado, temos a satisfação de apresentar o Professor Hugo Trevisi, que tem levado a Ortodontia brasileira para todos os rincões deste planeta, por meio da divulgação da filosofia MBT e, mais recentemente, da incorporação de um novo braquete de auto-ligação.

Na seção "O que há de novo na Odontologia", questiona-se a superioridade do uso do fio dental como auxiliar na higiene bucal, comparado ao uso de bochechos anti-microbianos. Também é apresentada uma curiosa pesquisa sobre as razões da existência do mento na estrutura mandibular, estrutura esta criada durante a evolução da espécie, mas que não mostrou-se mecanicamente útil.
Recebendo o "selo do editor" nesta edição, o artigo sobre os efeitos do aparelho Herbst na dentadura mista aponta os resultados que podem ser esperados para esta fase, salientando o forte componente dentoalveolar, e apresenta uma rica discussão sobre qual a fase mais clinicamente interessante para este tipo de correção.

Qual é o prognóstico do comportamento gengival quando protruímos os incisivos inferiores? Yared, Zenobio e Pacheco discorrem sobre este tema, apresentando uma revisão crítica da literatura que aponta as principais variáveis envolvidas.

Mais uma vez mostramos nossa preocupação quanto ao custo biológico do tratamento ortodôntico, ao selecionarmos o artigo que aponta o uso de dentifrícios contendo flúor-xilitol para o controle da placa bacteriana e da gengivite em pacientes jovens.

Principalmente voltado para os praticantes da técnica do arco segmentado, o estudo sobre alça "T" de Thiesen et al. apresenta as variações das proporções momento/força e carga/deflexão para dois tipos de desenhos, com e sem pré-ativação, para dois calibres de fio retangular, de aço e de beta-titânio.

No tema diagnóstico, são incluídos, ainda, um artigo sobre o comportamento do plano palatino em relação à base do crânio em pacientes normais e dois artigos sobre as características ântero-posteriores, dentárias e cefalométricas, na fase da dentadura decídua. Ainda é abordado, em dois estudos, o uso dos métodos de avaliação da maturidade esquelética, incluindo o método digital e convencional do índice de Grave-Brown, e uma comparação quanto ao uso do índice carpal versus o vertebral.

O fator estabilidade é motivo de preocupação constante em nossos consultórios. Será que as extrações de pré-molares melhoram o prognóstico? Qual a influência da curva de Spee na manutenção da correção vertical? Dois trabalhos do Departamento de Ortodontia da Faculdade de Odontologia de Bauru trazem à tona mais evidências sobre estes temas.

Uma avaliação da superfície da porcelana após a descolagem de braquetes aponta as melhores combinações de tempo de condicionamento com o ácido fluorídrico, bem como o uso do silano.

Por fim, um oportuno trabalho sobre os limites da distribuição de tarefas aos auxiliares, no consultório ortodôntico, discorre sobre o tema e apresenta um levantamento do que se tem praticado na região de Goiânia.

Finalizo este editorial com o mesmo entusiasmo do lançamento da Revista Dental Press de Ortodontia e Ortopedia Facial em setembro de 1996. Tenho a convicção de que toda a equipe compartilha deste sentimento de busca incansável pelo melhor, edição após edição. Impulsionados pelo respaldo de nossos leitores e amigos colaboradores, teremos mais e mais motivos para comemorar.

Parabéns pelos 10 anos de muito trabalho e do merecido sucesso! Feliz aniversário!

Adilson Ramos Editor 